\title{
Salmonella enterica 4,5,12:b:- serotipo berriaren karakterizazioa eta etxeko dortokekin erlazionatutako arriskua
}

\author{
(Characterization of the new serovar Salmonella enterica 4,5,12:b:- \\ and the risk associated with domestic turtles)
}

\author{
Ainhoa Arrieta-Gisasola*1, Joseba Bikandi Bikandi ${ }^{1}$, Javier Garaizar Candina ${ }^{1}$, \\ Silvia Herrera-León ${ }^{2}$, Lorena Laorden Muñoz ${ }^{1}$ \\ ${ }^{1}$ Immunologia, Mikrobiologia eta Parasitologia Saila, Farmazia Fakultatea, \\ Euskal Herriko Unibertsitatea (UPV/EHU), Vitoria-Gasteiz; Bioaraba, Vitoria-Gasteiz \\ ${ }^{2}$ Enterobakterioen unitatea, Mikrobiologiako Zentro Nazionala, \\ Carlos III. Osasun Institutua, \\ Ekonomia, Industria eta Lehiakortasun Ministerioa
}

\begin{abstract}
LABURPENA: Salmonelosia, herrialde garatuetako toxiinfekzio ohikoenetariko bat da, Salmonella generoko bakterioek eragindakoa. Oro har, giza salmonelosia elikagai kutsatuekin lotzen da. Hala ere, animaliekin izandako kontaktua Salmonella generoaren transmisio bide garrantzitsua izan daiteke. Dortokak Salmonella serotipo desberdinen gordailuak direla frogatu da. Narrasti hauek etxeko maskota oso ohikoak direla kontuan izanda, osasun publikorako arriskutsuak izan daitezke, batez ere haurren artean. Horregatik, lan honetan 4,5,12:b:- formula antigenikoa duen serotipo monofasiko berri bat karakterizatu da. Aztertutako isolatu gehienak 5 urtetik beherako haurretan isolatu dira, Espainiako eskualde desberdinetan. Teknika molekular ezberdinen bidez, baieztatu da 4,5,12:b:- isolatuak Paratyphi B Javako isolatu bifasikoekin genetikoki erlazionatuta daudela eta serotipo hori dela haren arbaso posiblea. Aztertutako anduien arteko homogeneotasun handiak iradokitzen du, andui horietaz infektatutako dortoken jatorria estuki lotuta dagoela, Espainian dortoken saltokiek banaketa-puntu komuna dutela, eta horrek patogeno honen sakabanaketan laguntzen duela.
\end{abstract}

HITZ GAKOAK: Salmonella enterica, aldaera monofasikoa, PFGE, dortokak, haurrak.

ABSTRACT: Salmonellosis, is one of the most common toxinfection caused by bacteria of the genus Salmonella in developed countries. In general, human salmonellosis is associated with contaminated food. However, contact with animals can be an important transmission route for Salmonella. Turtles have been shown to be reservoirs of different Salmonella serotypes. Considering that these reptiles are very common domestic pets, they can be a risk for public health, especially among children. In this work, a new monophasic serotype with the antigenic formula 4,5,12:b:- has been characterized. Most of the isolates analyzed have been isolated from children under 5 years of age in different regions of Spain. By means of different molecular techniques, it has been confirmed that 4,5,12:b:- isolates are genetically related to the biphasic isolates of Paratyphi B Java and that this serotype is their possible ancestor. The great homogeneity between the studied strains suggests that the origin of the turtles infected by these strains is closely related and that in Spain turtle shops have a common distribution point that contributes to the spread of this pathogen.

KEYWORDS: Salmonella enterica, monophasic variant, PFGE, tortoises, children.

* Harremanetan jartzeko / Corresponding author: Ainhoa Arrieta-Gisasola. Immunologia, Mikrobiologia eta Parasitologia Saila. Farmazia Fakultatea. Unibertsitate Pasealekua, 7 (01006 Vitoria-Gasteiz). - ainhoa.arrieta@ehu.eus - https://orcid. org/0000-0002-6406-8165

Nola aipatu / How to cite: Arrieta-Gisasola, Ainhoa; Bikandi Bikandi, Joseba; Garaizar Candina, Javier; Herrera-León, Silvia; Laorden Muñoz, Lorena (2021). "Salmonella enterica 4,5,12:b:- serotipo berriaren karakterizazioa eta etxeko dortokekin erlazionatutako arriskuan; Ekaia, 39, 2021, 23-36. (https://doi.org/10.1387/ekaia.21878).

Jasoa: 2020, ekainak 30; Onartua: 2020, abuztuak 14.

ISSN 0214-9001 - elSSN 2444-3255 / (C) 2021 UPV/EHU

(c) (i) () Obra hau Creative Commons Atribución 4.0 Internacional-en lizentziapean dago 
Ainhoa Arrieta-Gisasola, Joseba Bikandi Bikandi, Javier Garaizar Candina, Silvia Herrera-León, Lorena Laorden Muñoz

\section{SARRERA}

Salmonelosia osasun publikoko arazo garrantzitsua da mundu osoan zehar. Amerikako Estatu Batuetan (AEB), urtero 1,35 milioi kasu gertatzen direla kalkulatzen da [1]. Europan bakterioek eragindako gastroenteritisen bigarren eragilea da Salmonella, Campylobacter generoak eragindakoen ondoren [2]. Gaur egun, 2.600 Salmonella serotipo baino gehiago deskribatu dira, horietatik 2.000 gizakiengan eragina izan dezaketenak [3]. Salmonella generoak bi antigeno flagelar adierazteko gaitasuna du, lehenengo eta bigarren fasekoak, zeinak $f l i C$ eta $f l j B$ geneek kodetuak diren hurrenez hurren. Azken hamarkadetan, ordea, nabaria izan da fase bakarreko aldaera berrien agerpena. Aldaera monofasiko hauek, $f l j B$ genearen delezioaren ondorioz, ez dute bigarren faseko flageloa adierazten, eta epidemiologikoki oso garrantzitsuak bilakatu dira $[4,5]$.

Salmonella infekzioak beherakoa, gorakoak eta sukarra eragin ditzake [6]. Infekzioaren bilakaera klinikoa automugatua izan ohi da; hala ere, gaitz larriago bat eragin dezake arrisku handiko pazienteengan, hala nola haurrengan, adinekoengan edo immunoeskasidunak diren pazienteengan. Azken urteotan narrastiekin zuzenean edo zeharka lotutako salmonelosi-kasuen kopuruak gora egin du, batez ere etxean dortokak dituzten familien artean [7]. Oro har, animalia horien infekzioa sintomarik gabekoa da, nahiz eta larria edo are hilgarria ere izan daitekeen.

Batez ere Europan eta AEBetan azken urteetan izandako agerraldietan, ikerketak egin dira isolatuak identifikatzeko, non serotipo ezberdinak identifikatu diren bai pertsonen laginetan zein dortoken akuarioetan hartutako laginetan, hala nola Abgeni, Sandiego, Poona, Pomona, Paratyphi B Java, Newport, Typhimurium eta haren aldaera monofasikoa, Montevideo, Vitkin eta Abony [8-13]. Ildo honetan, 2020. urtean argitaratutako berrikuspen batek, azken hamar urteetan dortoken eta Salmonellaren arteko loturen berri ematen duen literatura eztabaidatzen du [14]. Han zehaztu da agerraldi gehienetan gaixoen proportzio altu bat bost urtetik beherako haurrak direla.

Euskal Autonomia Erkidegoan ere gertatu izan dira dortokekin erlazionatutako salmonelosi-kasuak. Bizkaiko Zaintza Epidemiologikoko Unitateak 2010eko irailaren eta 2011ko urriaren artean Salmonella Paratyphi B Java aldaerak eragindako 8 infekzio kasu detektatu zituen, eta beste 3 kasu aldaera monofasiko batek eragindakoak (4,5,12:b:-) [15]. Guztira, 11 kasu horietatik zortzi, 5 urtetik beherako haurretan gertatu ziren.

Salmonella Paratyphi B anduiek sukar paratifoideoa eta gastroenteritisa eragiten dute gizakietan [16]. Serotipo honen barruan, Java aldaera ezagutzen da, gizakietan birulentzia txikiagoa duena [15]. Java aldaeraz infektatutako gaixoek, beherako odoltsuak izan ditzakete, eta ager daitezke 
gorakoak, sukarra eta sabeleko kalanbreak ere [17]. Gainera, infekzio inbasiboen kasuak ere izan dira [16]. S. Paratyphi B Java biotipoaren gordailua animalia izanda, kutsatutako elikagaiekin erlazionatu izan da kasu isolatuetan, baita narrasti zein akuarioetako arrain tropikalekin ere [15].

Narrastiak Java aldaeraren eramaile arruntak dira beren hesteetan, eta normalean, ez dute gaixotasunaren seinalerik azaltzen. Bakterioak gorotzetan askatzen dituzte, eta animalia dagoen bizi-lekua kutsatzen dute, bai eta ura eta akuarioaren gainazal guztiak ere. Nahiz eta narrasti asko Salmonellaren eramaile izan, dortokek arrisku berezia dute, gure gizartean arrunta delako umeek dortoka txikiak maskotatzat izatea [15]. AEBetan urteroko 1,5 milioi salmonelosi-kasuetatik, 74.000 narrastien kontaktuarekin erlazionatuta daude. Salmonelosi-kasu guztien artean, kalkulatzen da \% 3-5 bitartean narrastiekin erlazioren bat dutela [7].

Gero eta gehiago dira Europan maskotatzat narrastiak dituzten familiak. Esposizio-modu horrekin lotutako salmonelosi-kasuen kopuruak gora egiten duela dirudien arren, oraindik ez da datu ofizialik argitaratu osasun-agintarien eskutik [7]. Gertakari horiek saihesteko programa bat ezarri aurretik, garrantzitsua da esposizio- eta transmisio-modua ezagutzea. Patogeno berrien detekzioa garrantzitsua izateaz gain, 2020. urte honetan pairatu dugun pandemian ikasi dugun bezala, patogeno berrien karakterizazioa ere ezinbesteko urratsa da bai ikertzaileentzat zein osasun-arloan mundu-mailan lan egiten duten agente guztientzat, patogenoen aurka modu egokian jardun ahal izateko. Beraz, lan honetan Espainiako eskualde desberdinetan 2006-2010 urteen bitartean isolatutako 38 Salmonella monofasiko aztertu eta karakterizatu dira: guztiek 4,5,12:b:- formula antigenikoa zuten.

Hau guztia kontuan izanda, artikulu honen helburu nagusiak honako hauek dira: batetik, Salmonellak gizakiengan eragindako infekzio-agerraldien inguruan informatzea, batez ere herritarrak kontzientziatzeko 5 urtetik beherako haurren osasunean dortokak bezalako maskotek izan dezaketen eragin larriaz; eta bestetik, Salmonella serotipo monofasiko berri baten agerpenaren berri ematea eta serotipo berri hori karakterizatzea.

\section{MATERIALA ETA METODOAK}

\subsection{Salmonella 4,5,12:b:- isolatuen bilduma eta PFGEaren bidezko karakterizazioa}

Ikerketa honetan, Mikrobiologiako Zentro Nazionalean (CNM) isolatutako Salmonella enterica espezieko 38 isolatu aztertu ziren. Guztiak 4,5,12:b:- formula antigenikoaren bidez izendatu ziren, eta antimikrobiarrekiko sentikorrak ziren. Isolatutako lagin gehienak 5 urtetik beherako 
Ainhoa Arrieta-Gisasola, Joseba Bikandi Bikandi, Javier Garaizar Candina, Silvia Herrera-León, Lorena Laorden Muñoz

umeetatik isolatu ziren. PCR kontrol moduan Salmonella Typhimurium LT2 anduia erabili zen. PFGEaren bidezko karakterizazioa PulseNet-ek estandarizatutako prozedurari jarraituz egin zen [18].

\subsection{Azpiespeziea determinatzeko PCRa}

Bilduma honen formula antigenikoa 4,5,12:b:- zela kontuan izanik, aldaera monofasiko hau Salmonella enterica espeziearen zer azpiespezieri zegokion jakiteko, PCR bat egin zen bildumako isolatu guztiekin. Izan ere, 4,5,12:b:- formula antigenikoa duten serotipoak $S$. enterica espeziearen bi azpiespezie desberdinetan daude: salamae azpiespeziean eta enterica azpiespeziean. Horretarako, DreamTaq ${ }^{\mathrm{TM}}$ Green PCR Master Mix sistema (Fermentas) baliatu zen. PCR erreakzioak $25 \mu l$-ko amaierako bolumenean egin ziren: irakite-metodoaren bidez erauzitako $5 \mu \mathrm{l}$ DNA, $1 \mu \mathrm{l}(1 \mu \mathrm{M})$ abiarazle bakoitzetik, $6 \mu \mathrm{l}$ miliQ ur esterila (Fermentas) eta $12 \mu$ l DreamTaq ${ }^{\mathrm{TM}}$ (Fermentas). Abiarazleak (phoP) CNMak emandakoak izan ziren. PCRaren baldintzak honako hauek izan ziren: hasierako inkubaldia $94{ }^{\circ} \mathrm{C}$-an 5 minutuz; ondoren, 25 ziklo $94{ }^{\circ} \mathrm{C} 30$ segunduz, $55^{\circ} \mathrm{C} 30$ segunduz eta $72{ }^{\circ} \mathrm{C} 100$ segunduz; eta azken elongazioa, $72{ }^{\circ} \mathrm{C}$-an 5 minutuz.

PCR produktuak 1x TAE (Tris-Azetato-EDTA) disoluzio indargetzailean prestatutako \% 1eko agarosa-gelean detektatu ziren (Pronadisa), elektroforesia 50 minutuz $100 \mathrm{~V}$-an egin eta gero. Ondoren, ChemiDoc XRS transiluminadorean (UVtransilluminator, Bio-Rad) bistaratu ziren. Pisu molekularraren markatzailetzat Hypperladder IV erabili zen (Bioline).

PCR produktuen purifikazioa GeneJet purification Kit-aren bidez egin zen (Fermentas). Fragmentuen sekuentziazioa Sistemas Genómicos S.A. (Valentzia, Espainia) enpresan egin zen, BigDye Terminator teknikari jarraituz. Kromatogramak DNAstar (Lasergene) programaren bidez aztertu ziren. Analisia eta lortutako sekuentzien konparaketa McQuiston eta haren lankideek [19] plazaratutako lanean egindako gomendioen arabera egin ziren.

\subsection{Java aldaeraren determinaziorako PCR espezifikoa}

Bildumako isolatuak Salmonella Paratyphi B-ren Java biotipoaren aldaera monofasiko baten isolatuak ziren ala ez frogatzeko, tartratoaren metabolismoarekin erlazionatutako geneekiko espezifikoak ziren abiarazleak erabili ziren. PCRa aurreko atalean deskribatutako DreemTaq ${ }^{\mathrm{TM}}$ sistema- $^{-}$ ren bidez egin zen. Abiarazleak CNMak eskainitakoak izan ziren, bai eta kontrol moduan erabilitako 2 anduiak ere (positibo eta negatibo moduan erabilitakoak). PCRaren baldintzak honako hauek izan ziren: hasierako inkubaldia $94{ }^{\circ} \mathrm{C}$-an 5 minutuz; ondoren, 25 ziklo $94{ }^{\circ} \mathrm{C} 30$ segunduz, $52{ }^{\circ} \mathrm{C}$ 
40 segunduz eta $72{ }^{\circ} \mathrm{C} 45$ segunduz; eta azken elongazioa, $72{ }^{\circ} \mathrm{C}$-an 7 minutuz.

\subsection{Bigarren faseko flageloaren delezioaren ikerketa}

\subsection{1. fljA, fljB, hin, iroB eta iroC geneen detekziorako PCRak}

Bigarren faseko flageloa kodetzen duen $f l j B$ genearen eta alboko geneen (fljA, hin, iroB eta iroC) presentzia edo galera frogatzeko, bost PCR egin ziren. Diseinatutako abiarazleak 1. taulan deskribatzen dira. PCR erreakzioak $25 \mu \mathrm{l}$ amaierako bolumenerako diseinatu ziren. Erreakzio bakoitzeko honako hauek erabili ziren: irakite-metodoaren bidez erauzitako $1 \mu \mathrm{l}$ DNA, $200 \mu \mathrm{M}$ dNTP, $1,50 \mathrm{mM} \mathrm{MgCl}{ }_{2}$, abiarazleen $0,4 \mu \mathrm{M}$ eta unitate 1 Taq polimerasa (Bioline, Londres, Erresuma Batua). PCRaren baldintzak honako hauek izan ziren: hasierako inkubaldia $94{ }^{\circ} \mathrm{C}$-an 2 minutuz; ondoren, 25 ziklo $94{ }^{\circ} \mathrm{C}$ minutu batez, $59{ }^{\circ} \mathrm{C}$ minutu batez eta $72{ }^{\circ} \mathrm{C} 2$ minutuz; eta azken elongazioa, $72^{\circ} \mathrm{C}$-an 5 minutuz.

1. taula. Bildumako isolatuen bigarren faseko flageloaren inguruko geneen presentzia/galera aztertzeko diseinatutako abiarazleak.

\begin{tabular}{|c|c|c|}
\hline STM geneak & $\begin{array}{l}\text { Nukleotido sekuentzia (5'-3') } \\
\text { Forward/Reverse }\end{array}$ & $\begin{array}{l}\text { Anplikoiaren } \\
\text { tamaina (bp) }\end{array}$ \\
\hline fljA (2770) & $\begin{array}{l}\text { CTCTCTTATGATGCCCGTGAACC/ } \\
\text { TGATATCCCTGTTCGATTGGTGAG }\end{array}$ & 614 \\
\hline$f l j B(2771)$ & $\begin{array}{l}\text { CAGCTCTGGTTGTGCTTTGA/ } \\
\text { GCCAACGACGGTGAAACTAT }\end{array}$ & 834 \\
\hline $\operatorname{hin}(2772)$ & $\begin{array}{l}\text { CATGAACAGGAACAGATTAGTCGGC/ } \\
\text { CAATCTTGTCACTGATACGGTCC }\end{array}$ & $54 / 59$ \\
\hline $\operatorname{iroB}(2773)$ & $\begin{array}{l}\text { GGA GAG CCG GTT ATC TCC AT/ } \\
\text { CCG CTC TTA CCG GGA ATA AT }\end{array}$ & 463 \\
\hline iroC (2774) & $\begin{array}{l}\text { CGG TAT GCG GGT AGT TCA GT/ } \\
\text { GGT CAG CGA GGT CAT TAA GC }\end{array}$ & 956 \\
\hline
\end{tabular}

PCR produktuak detektatzeko elektroforesia eta sekuentziazioa 2.2 atalean azaldu bezala egin ziren. Kromatogramak Chromas programaren bidez aztertu ziren (ChromasPro 1.5). Lortutako sekuentzien konparaketa eta analisia zenbait programa informatikoren bidez egin zen: Blast (https:// blast.ncbi.nlm.nih.gov/Blast.cgi), ADN/Protein alignment (http://insilico. ehu.es/align/) eta ClustalW (https://www.ebi.ac.uk/Tools/msa/clustalw2/), besteak beste. 
Ainhoa Arrieta-Gisasola, Joseba Bikandi Bikandi, Javier Garaizar Candina, Silvia Herrera-León, Lorena Laorden Muñoz.

\subsubsection{Alderantzizko PCRa eta sekuentziazioa}

Flageloa kodetzen duen genea $(f l j B)$ eta aldameneko geneen delezioaren hasiera- eta amaiera-muturrak zehazteko, genomaren eremu horretan, presentzia adierazi zuen genea (iroB) hartu genuen erreferentziatzat. iro $B$ genearen alboko eremuaren sekuentzia lortzeko, alderantzizko PCRa egin zen, honako prozedura honi jarraituz:

1. Sekuentziazioa hasteko iroB genea aukeratu zen, haren presentzia ezagutzen genuelako eta aurreko ikerketetatik ezagutzen genuelako iroB eta $f l j B$ geneen arteko gertutasuna [20].

2. Abiarazleen diseinua aukeratutako genearen muturretan egin zen, anplifikazioa genearen kanpoalderantz gertatzeko (iroBi; 5'-AGCAGCATGATCAATACCTTCCTCG-3', irobf; 5'-GGCCATTAACACGAAACGCTTG-3').

3. DNAren erauzketarako ADN mini kit-a (Qiagen) erabili zen. Erauzitako DNAren kuantifikazioa ND-1000 Spectrophotometer (Nanodrop, Delaware, USA) espektrofotometroaren bidez egin zen. Gomendagarria da $30 \mathrm{ng} / \mu \mathrm{l}$ eta $60 \mathrm{ng} / \mu \mathrm{l}$ arteko DNA kontzentrazioa izatea teknika egin ahal izateko.

4. DNA genomikoaren digestioa mozte-puntu gutxi dituen errestrikzio-entzima batekin egin zen. PstI (Fermentas) entzima aukeratu zen, ez zuelako mozte-punturik guk aukeratutako genean (iroB) eta 600 eta 900 zati bitartean sortarazten zituelako. Fabrikatzailearen urratsei jarraituz, PCRaren amaierako bolumena $50 \mu \mathrm{l}$-koa izan zen: $10 \mu \mathrm{l}$ DNA, $2,5 \mu \mathrm{l}$ PstI (15 U/ $\mu \mathrm{l}), 5 \mu \mathrm{l}$ PstI-en disoluzio indargetzaile eta 32,5 $\mu \mathrm{l}$ UD (Fermentas). Nahastea termoblokean inkubatu zen, $37^{\circ} \mathrm{C}$-an 4 orduz.

5. Entzimaren inaktibazioa egin zen, $65^{\circ} \mathrm{C}$-an eta 20 minutuz.

6. DNAren digestioa egiaztatzeko elektroforesia egin zen $\% 0,8 \mathrm{ko}$ agarosa-gelean 1x TAE-rekin, 90V-an 50 minutuz. Gela ChemiDoc XRS-ean (Bio-Rad) aztertu zen.

7. Digeritutako DNAren prezipitazioa, kloroformo: alkohol isoamiliko 24:1 soluzioarekin egin zen, 1:1 proportzioan. Ondoren, 5 minutuz $13.000 \mathrm{rpm}$-an zentrifugatu zen. Soluzioaren goiko fasea beste hodi garbi batera transferitu zen, eta 1:1-eko proportzioan nahastu zen alkohol isoamiliko: fenol: kloroformoarekin (hodi, Gatersleben, Saxony-Anhalt, Alemania). Berriz zentrifugatu zen, 5 minutuz $13.000 \mathrm{rpm}$-an. Goiko fasea beste hodi garbi batera transferitu zen, eta 1:0,6 proportzioan nahastu zen isopropanolarekin $\left(-20^{\circ} \mathrm{C}\right)$. Nahastea 10 minutuz zentrifugatu zen $13.000 \mathrm{rpm}-\mathrm{an}$. Gainjalkina kendu eta jalkinaren garbiketa egin zen, $100 \mu \mathrm{l}$ etanol absolutuarekin $\left(-20{ }^{\circ} \mathrm{C}\right)$; horretarako, $5 \mathrm{mi}-$ nutuko zentrifugazioa egin zen, $13.000 \mathrm{rpm}$-an. Ondoren, etanol guztia kendu zen, eta jalkina $37^{\circ} \mathrm{C}$-an lehortu zen, termoblokean. 
Behin etanol-soberakin guztiak lurrunduta, jalkina $20 \mu \mathrm{TE} \mathrm{pH} 8$ disoluzio-indargetzailean bersuspenditu zen.

8. Ligazioa T4 DNA ligasaren (Roche) bidez egin zen. Amaierako $30 \mu \mathrm{l}$ bolumenean prestatu zen honako nahasketa hau: $18 \mu \mathrm{l}$ UD (Fermentas), $3 \mu \mathrm{l}$ T4-ren disoluzio indargetzaile, $2 \mu \mathrm{l}$ T4 DNA ligasa $(5 \mathrm{u})$ eta $7 \mu$ l aurreko prezipitazioko DNA. Gau osoan mantendu zen $14{ }^{\circ} \mathrm{C}$-an.

9. Prezipitazioa 7. urratsean (DNA prezipitazioa) deskribatu den moduan egin zen, baina amaieran jalkinaren berresekitzea $15 \mu \mathrm{TE}$ $\mathrm{pH} 8$ disoluzio-indargetzailean egin zen.

10. Long-range PCRa burutzeko Expand Long Template PCR System kit-a (Roche) erabili zen. Erabilitako abiarazleak iroBi eta iroBf izan ziren.

11. PCR produktuak \% 0,8ko agarosa-geleko elektroforesian aztertu ziren, eta banden azterketa ChemiDoc XRS-aren (Bio-Rad) bidez egin zen. Pisu molekularraren markatzaile moduan erabili ziren X Markatzailea (Roche) eta GeneRuler DNA 100 bp Plus (Thermo Fisher Scientific). PCR produktuak GeneJet purification Kit-en (Fermentas) bidez erauzi eta purifikatu ziren.

12. Anplifikatutako produktuen klonazioa Escherichia coli anduietan egin zen produktuaren sekuentziaziorako zatien kopiak soberan izateko. Transformazioa Clonning TOPO kit-a (Invitrogen, Carlsbad, CA, AEB) erabiliz egin zen. Ondoren, hiru ereintza egin ziren Luria-Bertani-agar (LB) hazkuntza-medioaren bolumen ezberdineko $(50 \mu \mathrm{l}, 100 \mu \mathrm{l}$ eta $200 \mu \mathrm{l})$ Petri kutxatiletan eta $10 \mu \mathrm{l}$ anpizi-

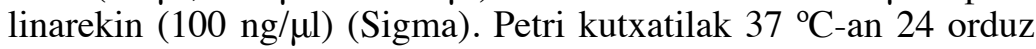
inkubatu ziren. Produktuak bektorean txertatu ziren E. coli zelula konpetenteetan transformazioa gertatu zela baieztatzeko, plasmidoen erauzketa QIAprep Spin Miniprep Kit-en (Qiagen) bidez egin zen. Ondoren, iroB genearen PCR anplifikazioa egin zen, Pure$\mathrm{Taq}^{\mathrm{TM}}$ Ready-To-Go Beads (GE Healthcare AB) sistema erabiliz. PCR anplifikazioa eta produktuen azterketa 2.4.1 den moduan egin zen.

13. Long-range PCRaren bidez lortutako produktuak tamaina handikoak izanik (2.000-9.000 bp), kateatutako sekuentziazioa (walking-primer) egin zen produktu osoaren nukleotido sekuentzia lortzeko. BLAST plataformaren bidez sekuentziatutako zatiaren hasiera aztertu ondoren, sekuentziazioa egiten jarraitzeko, abiarazle berriak diseinatu ziren. 
Ainhoa Arrieta-Gisasola, Joseba Bikandi Bikandi, Javier Garaizar Candina, Silvia Herrera-León, Lorena Laorden Muñoz

\section{EMAITZAK}

\subsection{Elektroforesia eremu pultsatuko gelean (PFGE)}

PFGE analisian ikertutako 38 isolatuen artean, 10 profil ezberdindu ziren (1. irudia). Profilen artean ez zeuden 12 banda baino gutxiagokoak, ez eta 15 baino gehiagokoak ere. Dena den, profil ezberdinen artean 4 banda baino gehiagoko ezberdintasunak aurkitu zirenez, isolatuak 5 pultsotipo ezberdinetan sailkatu ziren: A, B, C, D eta E. A pultsotipoa 3 azpimotatan banatu zen: A1 (27 isolatu zituena), A2 (1 isolatu) eta A3 (1 isolatu). B pultsotipoan, berriz, 3 isolatu sailkatu ziren, profil bera zutenak. C pultsotipoan, isolatu bakarra sailkatu zen, eta D pultsotipoan 3 azpimota aurkitu ziren, bakoitzean isolatu bakarra zegoela (D1, D2 eta D3). Profil nagusiarekiko ezberdintasun gehien erakutsi zituzten profilak E pultsotipoan batu ziren (E1 eta E2 azpimotak, isolatu bat bakoitzean). 0,48 balioko Simpson Indizearen Dibertsitatea (SID) kalkulatu zen.

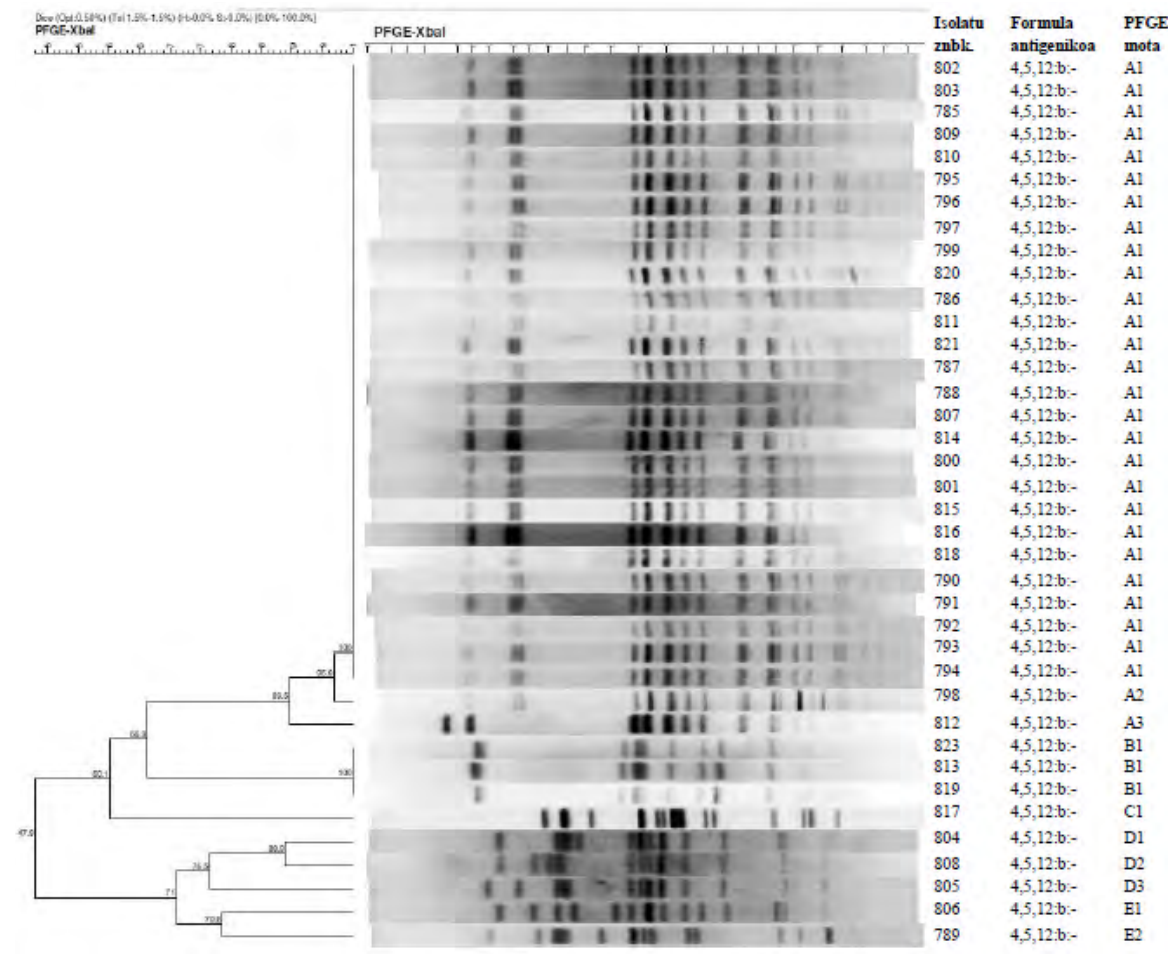

1. irudia. Dice-ren koefizientearen eta UPGMA taldekatzearen bidez PFGEko datuentzat eraikitako dendograma. 


\subsection{Azpiespeziea determinatzeko PCRa}

Artikulu honetan karakterizatzen den aldaeraren azpiespeziea determinatzeko, PCR bat egin zen bildumako isolatuetan. PCR horrek baieztatu zuen isolatu monofasiko guztiak Salmonella enterica espezieko enterica azpiespeziekoak zirela.

\subsection{Java aldaera determinatzeko PCR espezifikoa}

Bildumako isolatuak Salmonella Paratyphi B-ren Java biotipokoak ziren ala ez frogatzeko, tartratoaren metabolismoarekin erlazionatutako geneekiko espezifikoak ziren abiarazleak erabili ziren PCRan. Analisi honetan 38 isolatuetatik 37 positiboak izan ziren (esperotako tamainako zatiak anplifikatu zirelako). Beraz, egiaztatu zen 37 isolatu horiek Salmonella Paratyphi B Java aldaerako isolatu monofasikoak zirela.

\subsection{Bigarren faseko flageloaren delezioaren ikerketa}

\subsection{1. fljA, fljB, hin, iroB eta iroC geneak detektatzeko PCRak}

$f l j A, f l j B$, hin, iroB eta iroC geneen presentzia edo galera aztertzeko, 5 PCR egin ziren. Isolatu guztietan lortu zen anplifikazioa iroB eta iroC geneentzat. Beste alde batetik, $f l j A, f l j B$ eta hin geneen delezioa baieztatu zen aztertutako isolatu guztietan.

\subsubsection{Alderantzizko PCRa eta sekuentziazioa}

Bigarren faseko flageloaren delezioaren muturrak zehazteko orduan, eta eremu horren inguruan zeuden geneen kokapena ezezaguna zenez, alderantzizko PCRaren teknika egitea erabaki genuen. Anplifikazioan 1.600 bp-ko zatia lortu zen, eta sekuentziazioan iroB eta iro $C$ geneak bata bestearen jarraian agertzen zirela ikusi zen, Salmonella Typhimurium serotipoan deskribatzen den moduan (2. irudia). Fase bietako flageloak dituzten Salmonella anduietan, $S$. Typhimurium serotipokoetan adibidez, $f l j A$, $f l j B$, hin, iroB eta iroC geneak bata bestearen jarraian agertzen dira. Kasu honetan, ordea, sekuentziazioak erakutsi zuen $f l j A$, $f l j B$ eta hin geneak delezionatuta zeudela, eta haien lekuan honako sekuentzia (ezberdin) hauek zeudela txertatuta: transposasa bat kodetzen duen api81 genearen $183 \mathrm{nu}-$ kleotidoko sekuentzia bat, S. Typhimurium LT2 anduairen STM2745 genearen lehenengo 215 nukleotidoak eta, azkenik, STM2744 eta STM2743 geneak osorik (2. irudia). 
Ainhoa Arrieta-Gisasola, Joseba Bikandi Bikandi, Javier Garaizar Candina, Silvia Herrera-León, Lorena Laorden Muñoz.

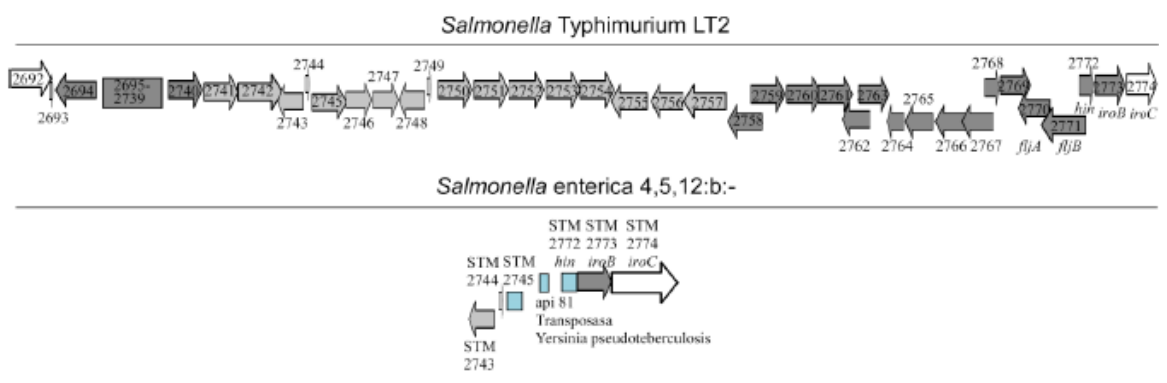

2. irudia. Ikerketagai izan diren isolatu talde nagusian aurkitutako delezioaren eskema (38 isolatuetaik 30etan), Salmonella Typhimurium LT2-rekin alderatuta.

\section{EZTABAIDA}

Salmonelosia osasun publikoan eragin handia duen arazoa da. Gero eta garrantzitsuagoa da dortokek gaixotasun horren eramaile gisa duten eginkizuna [14]. Salmonelosi-kasuak tokiko zaintza-agentziei jakinarazten zaizkie, eta horiek esposizio-iturriak baloratzeko ikerketak egiten dituzte. Gainera, azken urteetan serotipo monofasiko berrien agerpena gertatzen ari da, eta patogeno berri hauen detekzioa, ezagupena eta kontrola ezinbestekoa da osasun-agintariek beren ikerketa epidemiologikoetan kontuan izateko eta populazioaren segurtasuna bermatzeko.

Salmonella Paratyphi B, S. Paratyphi A eta C-rekin batera sailkatzen da Salmonella paratifoideoen barruan, zeinek sukar paratifoidea eragiten duten. Haren patogenizitatea dela eta, derrigorrezkoa da haren detekzioa eta osasun-agintariei kasuen berri ematea. Paratyphi B-ren barruan Java izeneko aldaera bat ezagutzen da: gehienetan kasu gastrointestinalak eragin arren, infekzio inbasiboen kasuak detektatu izan dira [16].

Azken urteetan zenbait lan argitaratu dira $S$. Paratyphi B Java aldaerak eragindako salmonelosi-kasuen berri ematen dutenak. Bereziki haurren kasuetan, maskotak izan dira infekzio-iturriak, adibidez arrain tropikalak edo dortokak $[8,9,14,15]$. Nabarmentzekoa da 1975an Food and Drug Administration (FDA) agentziak dortoken salmenta debekatu zuela dortokekin erlazionatutako salmonelosien intzidentzia murrizteko helburuarekin [17]. Hala ere, 2001-2006 bitartean, maskotatzat erabilitako dortoken kopurua \% 86an handitu zen Estatu Batuetan. Geroago, 2007an, Centers for Disease Control and Prevention (CDC) agentziak Java biotipoak eragindako salmonelosi-agerraldi garrantzitsu baten berri eman zuen. Agerraldi hau, Europan zehar hedatu zen, eta maskota-dendetan erositako dortokekin erlazionatu zen [21]. Nahiz eta CDC agentziak gomendioak eman dituen narrastien bidez emandako Salmonella kutsatzeak ekiditeko [22], oraindik narrastiekin erlazionatutako agerraldiak gertatzen dira. Hain zuzen ere, 2020ko urtarri- 
lean argitaratu berri du CDC agentziak dortokekin erlazionatutako azken salmonelosi-agerraldiaren ikerketa [23]. Beraz, badirudi dortoken salmentan eta banaketan debekuak jartzea dela modurik eraginkorrena kutsatze hauek saihesteko. Hala ere, gure herrian indarrean dagoen legedian ez da inongo debekurik jasotzen maskota mota honen merkaturatzean.

Ikerketa-lan honetan zehar, 4,5,12:b:- formula antigenikoa zuten 38 isolatu aukeratu ziren, jatorria Espainiako eskualde desberdinetan zuten eta gehienak 5 urtetik beherako umeetan isolatuak ziren. S. Paratyphi B $(4,5,12: \mathrm{b}: 1,2)$ Javarekin zuen ezberdintasun nagusia bigarren faseko flageloaren delezioa izanik, andui monofasiko izena eman zitzaien. Horregatik, andui monofasiko honen jatorria Salmonella Paratyphi B Javan zegoen aztertu zen, eta aldaera monofasiko berri hau karakterizatu zen.

Kauffmann eta White-ren eskemaren arabera, 4,5,12:b:- formula antigenikoko anduiak Paratyphi B serotipokoak izan litezke, baina baita beste serotipo edo azpiespezie batzuetakoak ere. Ikerketa honetako isolatuen arbasoa Salmonella enterica espezieko enterica azpiespeziekoa zela frogatu zen, phoP genearen sekuentziaren konparaketa-analisia eginez [19]. Ondoren, Salmonellaren tipifikaziorako erreferentzia teknika bezala, PFGEa egin zen bildumako 38 isolatuekin, Paratyphi B dT (+)-rekiko antzekotasuna analizatzeko asmoz. Nabarmentzekoa da 38 isolatuetatik $30 \mathrm{ek}$ (\% 78,9) PFGE profil bera aurkeztu zutela: bilduman detektatutako 5 profiletatik kopuru altua profil batean taldekatzeak bilduma honen homogeneotasun altua frogatzen du. Profil hauen konparaketak jatorriari buruz genuen hipotesia egiaztatu zuen: jatorria Salmonella Paratyphi B dT (+)-ean zegoela determinatu zen. Andui monofasikoen karakterizazio hobea lortu zen tartratoaren metabolismoarekin inplikatutako gene baten anplifikazioaren bidez. Emaitzek genearen presentzia baieztatu zuten 37 isolatuetan, Java aldaera bifasikoaren kasuan bezala. Bestalde, PCRan negatiboa izan zen isolatuaren arbasoa Salmonella Paratyphi B dT (-) izango litzateke.

Aldaera monofasiko honen karakterizazioa egiten amaitzeko, $f l j B$ genearen delezioaren ikerketa egin zen. Alderantzikatutako PCRaren bidez lortutako zatiek delezioaren hasiera STM2745 genean zegoela erakutsi zuten (partzialki delezionatuta) eta amaiera hin - iroB eskualde intergenikoan. Delezioaren erdian 183 bp-ko sekuentzia bat aurkitu zen. Sekuentzia hori Yersinia pseudotuberculosisen deskribatutako gene bati dagokio (api81), zeinak transposasa bat kodetzen duen. Beraz, ondoriozta daiteke STM2745 eta iroB (STM2773) geneen arteko delezioa zenbait transposasaren ekintzaren ondorio izan zela eta urteak aurrera egin ahala delezioaren barruan insertzio eta delezio gehiago gertatu direla transposasa baten zati bat mantendu delako soilik.

Ikerketa-lan honetan landutako eta deskribatutako kasuak eta agerraldiak adibide batzuk besterik ez dira. Hala ere, narrastiek, eta bereziki dortokek, Salmonellaren transmisioan duten paper garrantzitsua erakus- 
Ainhoa Arrieta-Gisasola, Joseba Bikandi Bikandi, Javier Garaizar Candina, Silvia Herrera-León, Lorena Laorden Muñoz

ten dute, bereziki bost urte baino gutxiagoko umeen artean. Gure ustez, funtsezkoa da transmisio horrek herrialdeetan duen eragina ebaluatzea, prebentzio-neurriak aplikatu eta sustatu ahal izateko. Azterketa epidemiologiko hauetan, azpimarratu nahi dugu $S$. Paratyphi B serotipoaren aldaera monofasikoaren detekzioa, kontrola eta jarraipena beharrezkoa izan beharko litzatekeela. Azkenik, narrastien salmenta-guneetako araudi espezifikoak eta mota horretako animalia bat erosi nahi duten familiak informatzea eta praktika onak erakustea oso baliagarriak izan litezke transmisio bide hau murrizteko.

\section{ONDORIOAK}

Ikerketa-lan honetan, Salmonella enterica espezieko enterica azpiespeziearen serotipo berri baten agerpena egiaztatzen da. Metodo molekularren emaitzek ahalbidetu dute serotipo berri honen agerpena bigarren faseko flageloaren delezioan dagoela zehaztea. Bildumako anduien delezioaren sekuentziazioan transposasa baten eta beste gene ezberdin batzuen sekuentzia zatiak detektatu izanak adierazten du karakterizatutako aldaera berri honen flageloaren delezioa zenbait insertzioren eta berrantolaketaren ondorio izan dela.

Teknika molekular ezberdinen bidez, baieztatu da 4,5,12:b:- isolatuak Paratyphi B Javako isolatu bifasikoekin genetikoki erlazionatuta dauden aldaera monofasikoak direla eta serotipo hori dela haren arbaso posiblea. Tipifikazio-metodo genetikoetan, aztertutako anduien arteko homogeneotasun handia detektatu da. Horrek iradokitzen du, andui hauetaz infektatutako dortoken jatorria komuna dela edo elkarri estuki lotuta dagoela, Espainian dortoken saltokiek banaketa-puntu komuna dutela, eta horrek patogeno honen sakabanaketan laguntzen duela.

\section{ESKER ONAK}

Esker onak eman nahi dizkiogu Mikrobiologiako Zentro Nazionalari (CNM) lan honetan erabilitako isolatuengatik. Artikulu hau UPV/EHUk finantzatutako doktorego aurreko bekari (A. A.-G.) esker idatzi da.

\section{BIBLIOGRAFIA}

[1] CDC. 2019. Antibiotic resistance threats in the United States. Department of Health and Human Services, Atlanta.

[2] EFSA, ECDC. 2019. «The European Union One Health 2018 Zoonoses Report». EFSA Journal 17. 
[3] Grimont, P., Weill, F. 2007. Antigenic Formulae of the Salmonella Serovars 9 th Edition.

[4] Toboldt, A., Tietze, E., Helmuth, R., Junker, E., Fruth, A., Malorny, B. 2013. «Population structure of Salmonella enterica serovar 4,[5],12:b-strains and likely sources of human infection». Applied and Environmental Microbiology, 79, 5121-5129.

[5] Sun, H., WAN, Y., Du, P., BAI, L. 2020. «The Epidemiology of Monophasic Salmonella Typhimurium». Foodborne Pathogens and Disease, 17, 87-97.

[6] Chen, H. M., Wang, Y., Su, L. H., ChIU, C. H. 2013. «Nontyphoid Salmonella infection: Microbiology, clinical features, and antimicrobial therapy». Pediatrics and Neonatology, 54, 147-152.

[7] Lafuente, S., Bellido, J. B., Moraga, F. A., Herrera, S., Yagüe, A., Montalvo, T., De Simó, M., Simón, P., CaYlà, J. A. 2013. «Salmonella Paratyphi B and Salmonella Litchfield outbreaks associated with pet turtle exposure in Spain». Enfermedades Infecciosas y Microbiologia Clinica, 31, 32-35.

[8] Ricard, C., Mellentin, J., Ben Abdallah Chabchoub, R., Kingbede, P., Heuclin, T., Ramdame, A., Bouquet, A., Couttenier, F., Hendricx, S. 2015. «Méningite à Salmonelle chez un nourrisson due à une tortue domestique». Archives de Pediatrie, 22, 605-607.

[9] Gambino-Shirley, K., Stevenson, L., Concepción-Acevedo, J., Trees, E., Wagner, D., Whitlock, L., Roberts, J., Garrett, N., VAn Duyne, S., McAllister, G., Schick, B., Schlater, L., Peralta, V., Reporter, R., Li, L., Waechter, H., Gomez, T., Fernández Ordenes, J., Ulloa, S., Ragimbeau, C., Mossong, J., Nichols, M. 2018. «Flea market finds and global exports: Four multistate outbreaks of human Salmonella infections linked to small turtles, United States - 2015». Zoonoses and Public Health, 65, 560-568.

[10] Bosch, S., Tauxe, R. V., Behravesh, C. B. 2016. «Turtle-associated salmonellosis, United States, 2006-2014». Emerging Infectious Diseases, 22, 1149-1155.

[11] Braun, S., Spalloni, W., Ferreccio, F., Postigo, J., Fernández, A., Porte, L., Saldivia, A., Wigant, W., Triantafilo, V. 2015. «Gastroenteritis por Salmonella spp. en tres lactantes asociada a contacto con tortugas acuáticas». Revista chilena de infectología, 32, 334-338.

[12] Angot, M., Labbe, F., DuQuenoy, A., Le Roux, P. 2017. «Rotavirus-Salmonella coinfection due to turtles: Two cases with exotic pets». Archives de Pediatrie, 24, 747-748.

[13] De Silva, B. C. J., Hossain, S., Wimalasena, S. H. M. P., Pathirana, H. N. K. S., WendT, M., HeO, G.-J. 2017. «Quinolone susceptibility and genetic characterization of Salmonella enterica subsp. enterica isolated from pet turtles». Laboratory Animal Research, 33, 49.

[14] Sodagari, H. R., Habib, I., Shahabi, M. P., Dybing, N. A., Wang, P., BRUCE, M. 2020. «A review of the public health challenges of Salmonella and turtles». Veterinary Sciences, 7. 
Ainhoa Arrieta-Gisasola, Joseba Bikandi Bikandi, Javier Garaizar Candina, Silvia Herrera-León, Lorena Laorden Muñoz.

[15] Hernández, E., Rodriguez, J. L., Herrera-León, S., García, I., de CasTRO, V., Muniozguren, N. 2012. «Salmonella Paratyphi B var Java infections associated with exposure to turtles in Bizkaia, Spain, September 2010 to October 2011». Eurosurveillance, 17, 1-5.

[16] Higginson, E. E., Ramachandran, G., Hazen, T. H., Kania, D. A., Rasko, D. A., Pasetti, M. F., Levine, M. M., Tennant, S. M. 2018. «Improving our understanding of Salmonella enterica serovar Paratyphi B through the engineering and testing of a live attenuated vaccine strain ». mSphere, $\mathbf{3}$, $1-11$.

[17] Harris, J. R., Bergmire-Sweat, D., Schlegel, J. H., WinPisinger, K. A., Klos, R. F., Perry, C., Tauxe, R. V, Sotir, M. J. 2009. «Multistate outbreak of Salmonella infections associated with small turtle exposure, 20072008». Pediatrics, 124, 1388-94.

[18] CDC. 2017ko abenduan eguneratua. «Standard Operating Procedure for PulseNet PFGE of Escherichia coli O157:H7, Escherichia coli non-O157 (STEC), Salmonella serotypes, Shigella sonnei and Shigella flexneri.» URL: https://www.cdc.gov/pulsenet/pdf/ecoli-shigella-salmonella-pfge-protocol508c.pdf

[19] McQuiston, J. R., Herrera-Leon, S., Wertheim, B. C., Doyle, J., Fields, P. I., TAuXe, R. V., LogSDOn, J. M. 2008. «Molecular phylogeny of the salmonellae: relationships among Salmonella species and subspecies determined from four housekeeping genes and evidence of lateral gene transfer events». Journal of Bacteriology, 190, 7060-7067.

[20] Laorden Muñoz, L., Herrera-León, S., Bikandi Bikandi, J., Garaizar CANDINA, J. 2017. «Salmonella enterica espeziearen andui monofasikoen karakterizazio molekularra eta epidemiologikoa». EKAIA Euskal Herriko Unibertsitateko Zientzia eta Teknologia Aldizkaria, 34, 65-76.

[21] Denny, J., Threlfall, J., Takkinen, J., Löfdahl, S., Westrell, T., VArela, C., Adak, B., Boxall, N., Ethelberg, S., Torpdahl, M., StraeteMANS, M., VAN Pelt, W. 2007. «Multinational Salmonella Paratyphi B variant Java (Salmonella Java) outbreak, August - December 2007». Weekly releases (1997-2007), 12, DOI: https://doi.org/10.2807/esw.12.51.03332-en.

[22] CDC. 2018ko abuztuan eguneratua. «Stay healthy around pet reptiles and amphibians». URL: https://www.cdc.gov/healthypets/publications/healthyaround-reptiles-and-amphibians.html

[23] CDC. 2020ko urtarrilean eguneratua. «Outbreak of Salmonella infections linket to pet turtles». URL: https://www.cdc.gov/salmonella/oranienburg10-19/index.html 